\title{
Nežymiai sutrikusio intelekto mokinių vertinimo ir ịsivertinimo būdų bei metodų ypatumai geografijos pamokose
}

\section{Regina Subotkevičienè}

Lietuvos edukologijos universitetas, Studentu g. 39, LT-08106 Vilnius

El.paštas regina.subotkeviciene@leu.lt
Subotkevičienė R. Nežymiai sutrikusio intelekto mokinių vertinimo ir įsivertinimo būdų bei metodų ypatumai geografijos pamokose. Geologija. Geografija. 2015. T. 1(3). ISSN 2351-7549.

Siekdami užtikrinti ugdymo kokybę, ypač kai klasèje yra ir specialiụjų poreikių mokinių, mokytojai turi kruopščiai suplanuoti savo veiklą - parinkti tinkamus ugdymo būdus ir formas, mokymo(si) metodus ir priemones, sukurti atitinkamą ugdymo(si) aplinką. Ne mažiau svarbi kiekvieno mokytojo sèkmingos veiklos dalis - mokinių pasiekimų vertimas ir įsivertinimas. Vertinimas plačiąja prasme orientuotas ị besimokančiụjų asmeninių galių plètojimą, adekvatų savo galimybių ir gebèjimų vertinimą. Jis turi atspindèti ko mokomasi, kas išmokta, kokiais būdais ugdymo procesas vyksta, ar jis vyksta neignoruojant individualių besimokančiojo mokymosi tempų ir būdų, atsižvelgiant ị besimokančiojo poreikius. Remdamasis vertinimo informacija, mokytojas suteikia pagalbą tiems mokiniams, kuriems jos reikia, pavyzdžiui, specialiujų poreikių mokiniams. Šiame straipsnyje, pasitelkus mokslinès literatūros ir empirinių tyrimo rezultatų analizę, apžvelgiami nežymiai sutrikusio intelekto mokinių vertinimo ir ịsivertinimo būdų bei metodų ypatumai geografijos pamokose.

Raktažodžiai: nežymiai sutrikusio intelekto mokiniai, mokymosi sunkumai, vertinimas ir ịsivertinimas, geografijos pamokos

\section{IVADAS}

Aktualumas. Vienas iš esminių šiuolaikinès švietimo sistemos bruožų - sudaryti sąlygas vaikams, turintiems raidos sutrikimų, mokytis pagal jų individualius gebejimus parengtas programas ir taikant specialiojo ugdymo mokomąsias priemones bei metodus siekiant optimalios mokymosi kokybės (Ambrukaitis, 1996; 2013). Tad kiekvienas mokytojas turi užtikrinti visų moksleivių poreikius bendrojo ugdymo mokykloje, kurie neleidžia pamiršti esminių socialinių, pedagoginių, psichologinių bei materialinių veiksnių. Šiame kontekste labai svarbi kiekvieno mokytojo sèkmingos veiklos dalis - mokinių pasiekimų vertimas ir issivertinimas. Lietuvos Respublikos švietimo ir mokslo ministro $2004 \mathrm{~m}$. vasario $25 \mathrm{~d}$. įsakyme „Dèl mokinių pažangos ir pasiekimų vertinimo sampratos“ pateikiama, kad vertinimas - „nuolatinis informacijos apie mokinio mokymosi pažangą ir pasiekimus kaupimo, interpretavimo ir apibendrinimo procesas“. Atlikus mokslinès literatūros analizę ir apibendrinus ìvairių autorių (Gage, Berliner, 1994; Jucevičiene, 1998; The New Oxford..., 1998; Laužackas, 2000; Kraujutaityte, 2005; Šiaučiukènienė ir kt., 2006; Pečiuliauskienè, Barkauskaitè, 2011; Indrašienè, Žibènienè, 2014 ir kt.) pateiktus vertinimo apibrèžimus, ji galima traktuoti kaip procesą, susidedantį iš informacijos kaupimo, interpretavimo, apibendrinimo ir kitų sistemingų vertinimo veiksmų. Vertinimo procesu siekiama tobulinti mokymą 
ir mokymąsi, skatinti motyvaciją, jis atspindi ugdymo proceso efektyvumą - ko mokomasi, kas išmokta, kokiais būdais ugdymo procesas vyksta, ar jis vyksta neignoruojant individualiu besimokančiojo mokymosi tempų ir būdų, atsižvelgiant $\mathfrak{i}$ besimokančiojo poreikius. Kalbant apie nežymiai sutrikusio intelekto mokinius integruotoje klasėje reikia pabrežti, kad jų vertinimas kaip tik ir yra pritaikytas specifiniams poreikiams, kurie nulemia formuluojamus vertinimo tikslus, modelius, metodus, būdus ir tipus.

Specialiujų poreikių mokinių pasiekimai ir pažanga vertinami vadovaujantis Mokinių pažangos ir pasiekimų vertinimo samprata, patvirtinta Lietuvos Respublikos švietimo ir mokslo ministro $2004 \mathrm{~m}$. vasario $25 \mathrm{~d}$. ịsakymu Nr. ISAK-256, Bendrosiomis programomis (2008), Pagrindinio ir vidurinio ugdymo programų bendraisiais ugdymo planais (2013-2014 ir 2014-2015) bei kiekvienos mokyklos Moksleivių pažangos ir pasiekimų vertinimo tvarkos aprašu. Svarbu paminèti, kad mokinių, turinčių specialiųjų ugdymosi poreikiu, ugdymas organizuojamas vadovaujantis šių mokinių ugdymo organizavimo tvarkos aprašu (2011). Specialiujuc poreikių mokinių mokymosi sunkumus ir gebejjimus, raidos specifikas bei kai kuriuos ju ugdymo organizavimo ypatumus tyrinëjo nemažai mokslininkų (Ališauskas, 2001; Ambrukaitis, 2001, 2013; Kugelmass, Ainscow, 2004; Koffemanas, 2005; Galkienè, 2013; Subotkevičiené, 2014 ir kt.), tačiau beveik nèra mokslinès literatūros apie specialiųjų poreikių mokinių vertinimo ir ísivertinimo būdus bei metodus pamokose. Kyla klausimai, ar iš tikrųjų visiems mokytojams aišku, kaip individualizuoti specialiųju ugdymo(si) poreikių mokinių vertinimą? Kokius vertinimo ir issivertinimo būdus bei metodus naudoti esant konkrečiam mokinio sutrikimui? Šaltinių analizė ir kylantys klausimai leidžia pabrèžti temos aktualumą ir formuluoti straipsnyje gvildenama problema - vertinimo ir įsivertinimo būdai bei metodai geografijos pamokose taikomi specialiųjų poreikių mokiniams nèra pakankamai atskleisti.

Suformulavus probleminius straipsnio teiginius, susiaurinamas ir apibrèžiamas straipsnio subjektas - nežymiai sutrikusio intelekto (arba labai žemų intelektinių gebejjimų) mokiniai.

Darbo tikslas - apžvelgti nežymiai sutrikusio intelekto mokinių vertinimo ir įsivertinimo meto- dų bei būdų, taikomų geografijos pamokose, ypatumus.

Uždaviniai:

1) aptarti nežymiai sutrikusio intelekto mokinių mokymosi sunkumus ir gebejjimų ypatumus, turinčius ịtakos šių mokinių pasiekimų vertinimui ir įsivertinimui;

2) pateikti kai kuriuos vertinimo ir įsivertinimo metodus bei būdus, padedančius organizuoti nežymiai sutrikusio intelekto mokinių mokymą(si) geografijos pamokose.

Tyrimo metodai - mokslinès literatūros ir empirinių tyrimo rezultatų analizè.

\section{NEŽYMIAI SUTRIKUSIO INTELEKTO MOKINIŲ MOKYMOSI SUNKUMAI IR GEBĖJIMŲ YPATUMAI}

Pasaulio sveikatos apsaugos organizacijos duomenimis, kasmet pasaulyje gimsta apie $11 \%$ vaiku, kuriems diagnozuojami ịvairūs vystymosi trūkumai ar sutrikimai. Remiantis Statistikos departamento duomenimis, Lietuvoje 2012-2013 m. m. specialiųjų poreikių mokinių buvo 40 348, t. y. $10,8 \%$ visu Lietuvos mokiniu. Tarp ivairiu vystymosi negaliu neretai pasitaiko intelekto bei protinio vystymosi sutrikimų. Remiantis tais pačiais duomenimis, tarp intelekto sutrikimų turinčiu mokinių Lietuvoje buvo 4847 vaikai.

I. Elijošienè (1998), A. Bagdonas (1995), J. Ambrukaitis ir J. Ruškus (2002) nurodo, kad protinis atsilikimas sudaro didžiausią intelekto sutrikimu grupę. Tai sutrikimas, kuris pasireiškia vaiko negrịžtamu pažintinès veiklos (ypač mąstymo proceso) pažeidimu, valios, emociju neišsivystymu, dažnomis fizinèmis negalemis. Daugelio autorių (Giedrienè, Monkevičienė, 1995; Pukinskaite, 1998; Ališauskas, 2001; Kugelmass, Ainscow 2004 ir kt.; Gedriené, 2013) nuomone, intelekto sutrikimas ir ribotumas ryškèja mokykliniame amžiuje ir pasireiškia mokymosi gebejjimų ir igūdžių formavimosi letumu, vangumu, neracionaliomis intelektinès veiklos strategijomis, nepakankamu juc kryptingumu; pažymimos mokymosi motyvacijos problemos, specifinis elgesys mokymosi veikloje, menkas darbingumas ir kt.

Protinis atsilikimas yra (Bagdonas, 1995):

- Nežymus - IQ 50-69 (suaugusiųjų protinis amžius nuo 9 iki 12 metų). Tikètina, kad gali kilti kai kurių mokymosi sunkumų mokykloje. 
- Vidutinis - IQ 35-49 (suaugusių protinis amžius nuo 6 iki 9 metų). Dažnas žymus protinès raidos sulètejjimas vaikystėje, tačiau vèliau igyjama tam tikro savarankiškumo save aptarnaujant.

- Žymus - IQ 20-34 (suaugusiųjų protinis amžius nuo 3 iki 6 metų). Suaugę reikalauja nuolatinés paramos.

- Labai žymus - IQ <20 (suaugusiųjų protinis amžius mažesnis nei 3 metų). Savarankiškumas, valyvumas, bendravimas ir judrumas labai apriboti.

Šiame straipsnyje aptariami tik nežymiai sutrikusio intelekto mokinių mokymosi sunkumai ir gebejjimų ypatumai, nes tik šị protinị atsilikimą turintys mokiniai gali mokytis bendrojo ugdymo mokyklose su savo bendraamžiais. Taip pat, remiantis straipsnio autorès patirtimi, bus akcentuojami jų mokymosi sunkumai ir gebejimų ypatumai geografijos pamokose.

Protiškai atsilikusiems vaikams sutrikusi yra jau pati pirmoji pažinimo grandis - suvokimas. $\mathrm{Pa}$ sak R. Kaffemano (2005), būdingi tokie suvokimo trūkumai: lètesnis tempas; suvokimas menkai diferencijuotas ir apibendrintas; suvokimo siaurumas; nepakankamas suvokimo aktyvumas. Aplinka bei mokomoji medžiaga suvokiama lètai, siaurai, fragmentiškai, nepakankamai diferencijuotai. Mokiniai aktyviai reaguoja it tuos dirgiklius, kuriuos jie jau pažista, ir gali labai menkai arba visai nesureaguoti ị labai svarbius, bet nežinomus. Todèl šių vaikų pasaulio pažinimas yra labai ribotas ir lètas. Remiantis Pagrindinio ugdymo pritaikymo rekomendacijomis (2010), galimi erdvès suvokimo sutrikimai, kurie išryškejja mokiniui mokantis rašyti, atliekant rankų darbus, formuojant vaizdinius, ypač reikalingus geografijos pamokose. Mokiniai, skaitydami tekstą, matydami gausybę iliustracijų, atlikdami tam tikras praktines užduotis, nuolat kuria geografinius vaizdinius. Tačiau erdvès suvokimo sutrikimai neleidžia labai žemų intelektinių gebejjimų mokiniams susidaryti pilno pasaulèvaizdžio. Labai dažnai aiškinat ir vaizdžiai rodant ivvairius geografinius objektus (pvz., žiotys, kalno papèdè, kaimo kraštovaizdis) jie ne visai supranta, kas tai yra, ir kitą pamoką paklausti paprasčiausiai neįstengia nusakyti jų esminių bruožų. Ką jau besakyti apie abstraktesnius geografinius objektus, reiškinius ar procesus - rinka, užterštumas, klimatas, pasaulio ūkis, atmosferos slègis, miškingumas, elektroenergetika. Pilnam pasaulio vaizdui susifor- muoti trukdo mokomosios medžiagos suvokimo fragmentiškumas - prisimenama tik ryškiausiai ìstrigusi informacija, kuri labai dažnai būna kiekvienam tą pati sutrikimą turinčiam vaikui gana individuali. Erdvinio suvokimo sutrikimas taip pat neleidžia tinkamai orientuotis aplinkoje. Jie neịsimena pagrindinių pasaulio krypčių, nesugeba susigaudyti pagal gamtos požymius (pvz., skruzdèlynus, samanas, tankesnę medžių lają), sunkiai orientuojasi plane ir žemèlapyje, nors pagrindinius sutartinius ženklus gali puikiai prisiminti.

Nežymiai sutrikusio intelekto mokiniams yra būdingi loginio mątymo operaciju sutrikimai, pasireiškiantys nesugebejjimu adekvačiai apibendrinti, abstrahuoti, lyginti, nustatyti loginius ryšius, santykius tarp daiktų ir reiškinių, daryti išvadas, spręsti uždavinius, planuoti bei numatyti rezultatus ir pan. Minètų mokinių mąstymas gerokai ilgesnị laiką nei kitų mokinių būna vaizdinis-veiksminis. Ši aplinkybè labai apsunkina mokymosi procesą. Tokiems mokiniams ypač sunku daryti išvadas. Išmokę taisyklę atmintinai, nemoka jos taikyti praktikoje ar pailiustruoti pavyzdžiais, o dèl prasto gebejimo apibendrinti blogai supranta apibendrintas tam tikros rūšies užduočiu atlikimo taisykles. Mokinių menkas mąstymo kūrybiškumas. Jie dažnai negali deramai dalyvauti įvairiuose žaidimuose, pratybose, nes nesupranta taisyklių, instrukcijų. Jų mąstymui būdingas nelankstumas, lètumas, siaurumas, paviršutiniškumas, nekritiškumas (Pagrindinio ugdymo..., 2010; Stankute, 2011). Loginio mąstymo operacijų sutrikimai labai apsunkina nežymiai sutrikusio intelekto mokinių geografijos žinių ir gebejiimų įsisavinimą. Jiems labai sunku nustatyti daugelio geografinių reiškinių priežasties ir pasekmès ryšius (pvz., kaip susiję Žemès sukimasis aplink Saulę ir dienos trukmè), lyginti ịvairius geografinius objektus (pvz., kalnus, šalis, naudingąsias iškasenas), remiantis statistine medžiaga daryti išvadas apie tam tikrus procesus (pvz., analizuoti kelerių pastarųjų metų bendrą Lietuvos gyventojų skaičių ir padaryti išvadas apie tai), prognozuoti ịvykius (remiantis tais pačiais gyventojų duomenimis, numatyti ateities perspektyvas). Kitais žodžiai tariant, nežymiai sutrikusio intelekto mokiniai beveik neịstengia atsakyti iz vieną esminių geografijos klausimų - kodèl?

Anot R. Koffemano (2005), formuojantis mąstymui, labai svarbus yra kalbos vaidmuo. Mąstymas ir kalba yra glaudžiai susiję. Kalbos neišsivystymas 
sudėtingą daro ir mąstymo raidą. A. Garšvienè ir R. Ivoškuvienè (1993) teigia, kad protiškai atsilikusio vaiko poreikis bendrauti, pažinti pasauli yra labai menkas. Mokiniai, kurių intelekto sutrikimas nežymus, turi kalbos supratimo, tarimo trūkumų. Šių vaikų žodynas skurdus dèl ribotų vaizdinių apie aplinkini pasaulį, nesusiformavusių interesų, kalbinių kontaktų, poreikių, silpnos atminties. Dèl šios priežasties nežymiai sutrikusio intelekto mokiniai gali neteisingai perskaityti ir suvokti daugelị geografinių sąvokų, ypač tų, kurias jiems sunku ištarti (pvz., kondensacija, šerkšnas, konvekcija ir pan.).

Dar viena mokymą(si) sunkinanti savybè - atminties specifiškumas. Pasak I. Elijošienès (1998), sutrikę yra visi atminties procesai - i̇siminimas, išlaikymas, atpažinimas ir atgaminimas. Mokiniai geriau įsimena tą medžiagą, kuri juos domina, sužadina emocijas, pateikiama vaizdžiai. Ypač sunkiai įsimenama abstrakti, sudètinga medžiaga, reikalaujanti loginès atminties. Todèl gamtinès geografijos objektai ir reiškiniai žymiai geriau ìsimenami, nei abstraktesni socialinès aplinkos. Labai daug medžiagos neišsilaiko vaikų atmintyje - ji užmirštama. Dažnai mokiniai prisimena atsitiktinius dalykus - atskirus faktus ir pavyzdžius vietoj taisyklių ir išvadų. Pavyzdžiui, jiems puikiai sekasi prisiminti, kad Pasaulio vandenyno vanduo sūrus, kad Kolumbas atrado Ameriką, aukštų kalnų viršūnès padengtos sniegu arba išskirtinius Afrikos tautų gyvenimo būdo bruožus net be gilesnio paaiškinimo, lyginimo ar interpretavimo. Kita vertus, labai dažnai atgaminama medžiaga būna netiksli ir kartais supainiojama su panašia (pvz., apibūdinant ir lyginant pasaulio religijas, kaimo ir miesto skirtumus, kritulių rūšis). Taip pat svarbu pabrèžti, kad jų požiūriu nesudètingą informaciją stengiamasi prisiminti ir atpasakoti pažodžiui, tačiau praleidus dalị teksto atgaminimas tampa beprasmis. Labai gaila, bet tai yra nesąmoningo, mechaninio mokymosi rodiklis.

Pagrindinio ugdymo bendrujų programų pritaikymo rekomendacijose (2010) dar išskiriami dèmesio bei savireguliacijos sutrikimai, turintys ittakos visam mokymui(si). Labai žemų intelektinių gebėjimų (nežymiai sutrikusio intelekto) mokinių demesys dažniausiai yra nevalingas, pasyvus, ji sukeliantys įvykiai nesusiję su žmogaus veiklos tikslu ir valios pastangomis. Tokie moki- niai greičiau atkreipia dèmesị $\mathfrak{i}$ daiktus, ryškiai išsiskiriančius iš aplinkos savo spalva, forma, garsais ir kt. Todèl nežymiai sutrikusio intelekto mokiniams vaizdžios ir įdomios geografijos pamokos dažnai patinka, ypač jei mokytojai rodo filmus ir nuotraukas, pateikia įdomių faktų, naudoja aktyvius mokymosi metodus, didaktinius žaidimus, organizuoja išvykas. Tačiau mokiniui yra sunku sutelkti dèmesị $\mathfrak{i}$ tikslingą, kryptingą, planingą veiklą. Net jeigu ir pavyksta ji sutelkti, tai trumpam. Dalis nežymiai sutrikusio intelekto mokinių dèl nuolatinès jaudinimo būsenos yra impulsyvūs, neramūs, išsiblaškę, todèl dažnai neišklauso žodinių instrukcijų, skaitydami praleidinejja raides, žodžius, skaito spèliodami, nesilaikydami skyrybos ženklų. Pasakodami gali įterpti žodžių, sakinių, nesusijusių su situacija. Nevalingą dèmesi gali apsunkinti emocinis nebrandumas, pasireiškiantis jausmų primityvumu, nepakankamu diferencijuotumu ar neadekvatumu konkrečiai situacijai, staigia nuotaikų kaita (Pagrindinio ugdymo..., 2010). Tokiais atvejais labai didelè pagalba geografijos mokytojui - nuolatinis kontaktas pamokoje, pagyrimai, paskatinimai ir, be abejonès, mokinių veiklos planavimas prieš kiekvieną pamoką.

Apibendrinant galima teigti, kad siekiant objektyviai vertinti nežymiai sutrikusio intelekto mokinius geografijos pamokose ir skatinti patiems issivertinti, reikia nuolat turèti omenyje ju gebejjimus ir mokymosi sutrikimus, kurie pasireiškia sutrikusiu suvokimu, loginio mąstymo ir dèmesio stoka, atminties specifiškumu, kalbos neišsivystymu bei emociniu nebrandumu. Taip pat svarbu pabrèžti, kad kiekvienam mokiniui dalis ar net daugelis šių ypatumų gali būti nebūdingi, nes mokinių specialieji poreikiai ir mokymosi sutrikimai būna labai ịvairūs. Todèl organizuojant geografinị ugdymą svarbu atsižvelgti $\mathfrak{i}$ kiekvieno konkretaus vaiko unikalumą, pažinti mokinio asmenybę bei turèti žinių apie mokinio socialinę aplinką.

\section{VERTINIMO IR İSIVERTINIMO BŪDAI BEI METODAI, TAIKOMI NEŽYMIAI SUTRIKUSIO INTELEKTO MOKINIAMS GEOGRAFIJOS PAMOKOSE}

Bendrojo ugdymo mokyklose organizuojant ugdymo procesą galima pasitelkti ịvairius vertinimo 
ir ịsivertinimo metodus, tačiau svarbu pasikliauti tais, kurie igalintų mokinius sèkmingai mokytis, padètų kurti palankią mokymo(si) aplinką, skatintų jų motyvaciją ir norą būti aktyviais. Apie vertinimo būdus ir metodus bei jų taikymą ugdyme yra nemažai literatūros, bet mokytojams trūksta argumentuoto pagrindimo, kokius veiksminga naudoti geografijos pamokose dirbant su sutrikusio intelekto mokiniais.

Geografija - tai mokslų sistema, apimanti gamtos ir visuomenès mokslų šakas, kurios tiria gamtinius ir gamybinius teritorinius kompleksus ir jų komponentus. Tai vienas labiausiai integruotų mokomųjų dalykų mokykloje. Bendrosiose programose (2009) yra keliamas toks geografijos ugdymo tikslas - pletoti mokinių geografini pasaulèvaizdi, skatinti domètis savo ir kitu šaliu gamtos bei visuomenès įvairove, plèsti geografijos žinias ir supratimą, padèti ugdytis socialinę kompetenciją. Siekdami tikslo, mokiniai mokosi orientuotis gamtinejje ir visuomeninejje aplinkoje, naudoja kartografinius kūrinius kaip patikimus informacijos šaltinius, renka ir analizuoja įvairiuose informaciniuose šaltiniuose pateikiamą informaciją, kritiškai ją vertina, domisi Lietuvos ir kitų šalių gamtos bei visuomenès įvairove, ịvairia geografine veikla, aktyviai tiria savo ir kitų kraštų gamtinę ir visuomeninę aplinką, susipažista su ja. Ugdymo procese integruojamos šios veiklos sritys: orientavimasis erdvèje ir žemèlapyje, geografinès informacijos skaitymas, regionų pažinimo raiška bei aplinkos pažinimas ir tyrimai. Atsižvelgiant ị mokinio patirtí, žinias ir gebejjimus, geografijos supratimo augimą, kiekvieno koncentro turinys nagrinejjamas lokalioje, regiono ir globalioje geografineje erdveje (Bendrosios programos, 2009).

Geografija nežymiai sutrikusio intelekto mokiniams padeda ugdyti geografinit pasaulèvaizdį, skatinti domètis savo ir kitų šaliu gamtos bei visuomenès ịvairove, formuoti pozityvų požiūrị i supančią aplinką, saugų elgesi gamtineje ir visuomenineje aplinkoje (Pagrindinio ugdymo..., 2010). Igyvendinant ši tikslą, geografijos mokytojams reikia siekti sukurti tokias mokymosi strategijas, kurios leistų šiuos sutrikimus turinčius mokinius išmokyti mokytis, būti kuo labiau savarankiškais, planuoti laiką, lavinti skaitymo, klausymo, praktinių darbų atlikimo bei savo darbo vertinimo gebejimus. Tačiau norint užtikrinti sklandų ir pil- naverti ugdymą, mokytojui taip pat labai svarbu gebėti tinkamai vertinti šių mokinių žinias, igūdžius, bendrus ir dalykinius gebejimus, nustatyti mokymo(si) pažangą.

Nežymiai sutrikusio intelekto mokiniams, pasižymintiems suvokimo stoka ir mąstymo specifiškumu, turi būti ypač aišku ne tik $k q$ jie turi atlikti pamokoje, bet ir kaip jie bus už tai vertinami. Šioje situacijoje yra sudètinga kalbèti apie šio sutrikimo mokiniu issivertinimą ir refleksiją, nes jiems būdingas emocinis nebrandumas ir savireguliacijos sutrikimai. Staigi nuotaiku kaita, emocijų nevaldymas, neadekvatus elgesys arba atvirkščiai - dažnas abejingumas - trukdo intelekto sutrikimų turintiems mokiniams objektyviai issivertinti ir reflektuoti savo veiklą. Priklausomai nuo nuotaikos, jie gali būti linkę pervertinti save arba kaip tik aiškinti, kad viskas blogai ir nesiseka. Nežymiai sutrikusio intelekto mokiniai ne visada gali kontroliuoti save ir sunkiai patys sau vadovauti. Tad šioje situacijoje labai svarbūs pagyrimai, išskirtinis dèmesys ar kitoks mokinio paskatinimas. Tai gali būti traktuojama ir kaip grịžtamasis ryšys - informacija apie veiklos rezultatus ir ju veiksmingumą. Tačiau visiems mokiniams reikia grižtamosios informacijos pažymiais, balais, taškais, o ne tik žodžiu. Pažymiai atspindi mokymo(si) rezultatus. Vertinant pažymiais sutrikusio intelekto mokinius, geografijos mokytojas turi laikytis tų pačių reikalavimų kaip ir visai klasei. Pažymiai turi būti objektyvūs, diferencijuoti (atsižvelgiant i mokinio pastangas ir parengtą individualizuotą programą), suprantami ir aiškūs (Indrašienè, Žibènienè, 2014). Priklausomai nuo pamokos konteksto, šiuos reikalavimus galima papildyti komentarais raštu ar žodžiu. Apibendrinus anksčiau išdèstytas mintis ir įvertinus dalyko ugdymo tikslus, galima teigti, kad nežymiai sutrikusio intelekto mokiniams geografijos pamokose gali būti taikomi formaliojo (vertinimas pažymiais, taškais, balais), neformaliojo vertinimo būdai (nuolatinis stebejimas kalbantis, diskutuojant, jaučiant grị̌žtamajji ryšị) bei kaupiamasis vertinimas. Pastarasis ypač veiksmingas tada, kai mokiniai atlieka užduotis per kelias nustatytas pamokas. Kaskart taikomi tarpiniai, o pabaigoje į dienyną įrašomas galutinis ivertinimas. Tokiu atveju sutrikusio intelekto mokinys suinteresuotas dirbti per visą mokymo(si) procesą, o ne epizodiškai. Tai sudrausmina bei 
skatina šio sutrikimo mokinių savikontrolę ir mokymo(si) motyvaciją.

Aptariant vertinimo būdų galimybes kyla klausimas - kokie vertinimo ir isivertinimo metodai yra efektyviausi geografijos pamokose dirbant su labai žemų intelektinių gebėjimų mokiniais? Tenka pabrèžti, kad vienareikšmiško atsakymo néra. Tai lemia ịvairūs veiksniai - mokytojo kompetencija, mokinio asmeninès savybès, klasès mikroklimatas, geografijos pamokos tema ir daugelis kitu individualių aplinkybių. Todèl šioje straipsnio dalyje, atsižvelgiant ị geografijos dalyko specifiką ir remiantis autorès asmenine patirtimi, atskleidžiami tik kai kurie geriausiai tinkantys šioms pamokoms vertinimo ir įsivertinimo metodai.

Individuali žodiné apklausa - mokymo(si) rezultatų vertinimas individualiai klausinejjant. Šis metodas leidžia mokiniui ramiai, nuosekliai ir rišliai atsakinèti. Sutrikusio intelekto mokiniui leidžiama naudotis paties sudarytu planu. Tačiau būtų gerai, jei mokiniai atsakinètų tik geografijos mokytojui girdint arba retais atvejais prieš visą klasę, kadangi jiems būdingas lètesnis kalbèjimo tempas, sunku išlaikyti dèmesî, reaguoja ị pašalinius dirgiklius, iš susijaudinimo gali netaisyklingai tarti žodžius, praleisti raides arba ị atsakymą įterpti su kontekstu nesusijusių žodžių. Kitiems pamokoje dalyvaujantiems gali būti nuobodu, kilti šurmulys bei atsirasti pašaipos. Tad mokytojas, tinkamai suplanavęs pamoką, gali rasti laiko apklausti tik ši mokinit. Toks metodas yra tinkamas toms geografijos temoms, kuriose pateikiama nemažai tekstinès medžiagos, sudominančios sutrikusio intelekto mokini, ir jis, pasinaudodamas savo planu, gali nesunkiai ją atgaminti. Pavyzdžiui, apie didžiuosius geografinius atradimus ir žymiausius keliautojus, geografinių zonų augalijos ir gyvūnijos ypatumus, pasaulio gyventojų ivvairovę.

Viešai kalbèti prieš visą klasę nežymiai sutrikusio intelekto mokiniams gali būti naudinga, jei jie daro pranešimą, kurio prieš tai niekas negirdejo. Be abejonès, pranešimo turinys turi atitikti mokinio gebejimus, o ji parengti galima individualiai konsultuojant mokytojui arba dirbant grupeje su kitais mokiniais. Geografijos mokytojas turi parengti pranešimo įvertinimo kriterijų ir jų aprašymų lentelę, kuri padètų tinkamai ir objektyviai ịvertinti kiekvieną pranešèją, tarp jų - ir sutrikusio intelekto (lentelè).

Pranešimo tematika gali būti labai įvairi ir priklausyti nuo geografinio ugdymo koncentro, mokinio amžiaus, jo individualių geografinių gebèjimų ir žinių.

\section{Le ntelè. Pranešimo įvertinimo kriterijų pavyzdžiai}

Table. The examples of the criteria of the report evaluation

\begin{tabular}{|c|c|c|c|}
\hline $\begin{array}{l}\text { Kriterijus } \\
\text { The criterion }\end{array}$ & $\begin{array}{c}\text { Kriterijaus aprašas } \\
\text { Description of the criterion }\end{array}$ & $\begin{array}{l}\text { Buvo } \\
\text { taikyta } \\
\text { It was } \\
\text { applied }\end{array}$ & $\begin{array}{l}\text { Nebuvo } \\
\text { taikyta } \\
\text { It was not } \\
\text { applied }\end{array}$ \\
\hline \multirow[t]{3}{*}{$\begin{array}{l}\text { Gebejimas rišliai pristatyti } \\
\text { The ability to present fluently }\end{array}$} & $\begin{array}{l}\text { Taisyklingai vartojami žodžiai } \\
\text { The words are used correctly }\end{array}$ & + & \\
\hline & $\begin{array}{l}\text { Suprantamos vartojamos geografijos sąvokos } \\
\text { The words of geographical concepts are understood }\end{array}$ & + & \\
\hline & $\begin{array}{c}\text { Pristatomas vientisas ir suprantamas tekstas } \\
\text { The text is solid and understood }\end{array}$ & & \\
\hline \multirow[t]{2}{*}{$\begin{array}{l}\text { Gebejimas sudominti } \\
\text { The ability to interest }\end{array}$} & $\begin{array}{l}\text { Taikomos vaizdinès geografinès priemonès } \\
\text { The visual geographical means are applied }\end{array}$ & & \\
\hline & $\begin{array}{l}\text { Tikslingai naudojama kūno kalba } \\
\text { The body language is used correctly }\end{array}$ & & + \\
\hline \multirow[t]{2}{*}{$\begin{array}{l}\text { Gebejimas panaudoti informaciją } \\
\text { The ability to use the information }\end{array}$} & $\begin{array}{l}\text { Naudojama geografinè informacija iš kelių } \\
\text { skirtingų šaltinių } \\
\text { The geographical information from several sources } \\
\text { is used }\end{array}$ & + & \\
\hline & $\begin{array}{l}\text { Naudojama patikima geografine informacija } \\
\text { Reliable geographical information is used }\end{array}$ & & \\
\hline
\end{tabular}


Savarankiškai ar grupèse su kitais mokiniais atliktoms užduotims, bandymams ar sukurtiems geografinių objektų modeliams ịvertinti gali būti taikomas vaizdinis metodas - pristatymas. Jis leidžia ịvertinti ne tik atlikto darbo kokybę, bet ir svarbius, sunkiai ugdomus šio sutrikimo mokinių gebejimus - vizualizuoti, sisteminti, lyginti. Pristatymui ivertinti geografijos mokytojas taip pat turi sugalvoti visiems aiškius ir suprantamus vertinimo kriterijus. Pavyzdžiui, geografinès informacijos patikimumas, vaizdumas ir pan.

Nežymiai sutrikusio intelekto mokinių geografijos pasiekimams ịvertinti tinka ịvairūs vertinimo raštu metodai - pavyzdžiui, apklausa raštu, testai. Tačiau būtina pabrèžti, kad klausimynai turi būti sudaryti atsižvelgiant ì mokinių žemus ir labai žemus intelektinius gebejimus - trumpi, aiškiai suformuluoti, nereikalaujantys sudètingo apibendrinamojo mąstymo, labai dažnai atkartojantys prieš tai pamokose pateiktas užduotis.

Norètųsi pažymèti, kad nepaisant atsakinèjimo formos geografijos pamokose šių intelekto sutrikimų turintiems mokiniams dažnai leidžiama naudotis papildomomis priemonèmis - žemélapiais, pratybomis, schemomis, paveikslais, grafikais, lentelemis, paties sudarytu planu arba, tam tikrais atvejais, vadovelio ar kito šaltino tekstu. Jei mokiniai atsakinèja raštu, geografijos mokytojui būtina periodiškai teirautis, kaip jiems sekasi. Taip besimokantieji mažiau blaškosi ir atidžiau susitelkia ties atsakymais.

Remiantis nuostata, kad visų gebejimų mokinius reikia ugdyti aktyviais, atsakingais asmenimis, kryptingai tobulejjančiais, verta akcentuoti mokejjimo įsivertinti svarbą. Anot G. Petty (2008), ugdyme tiesiog būtini metodai, nukreipti ị savirefleksiją ir ịsivertinimą. Atsižvelgiant $\mathfrak{i}$ anksčiau aprašytus sutrikusio intelekto mokinių sutrikimus, mokymo(si) sunkumus ir autorès patirti, geografijos pamokose rekomenduojama taikyti kai kuriuos geografijos mokymo(si) motyvaciją ir teigiamą nusiteikimą keliančius įsivertinimo metodus (tik juos prieš tai pritaikius mokinių intelekto sutrikimui):

- Blyksnis - skirtas žaibiškai ịvertinti savo veiklą esamu momentu. Mokinys tiesiog labai trumpai ir aiškiai pasisako nagrinejjamu klausimu (pvz., jei mokinio užduotis surasti žemèlapyje 10 didžiausių pasaulio miestų, mokytojas gali paklausti - kokio miesto ieškoma, kiek jau suradai ir pan.).
- Mozaika - taikoma, kai norima žaismingai išsiaiškinti mokinių savijautą ar požiūrị nagrinèjama tema ar klausimu. Metodo esmé - spalvų ir pojūčių prasmès. Pavyzdžiui, raudona spalva - mane nervina ir erzina, geltona - man patinka, balta - man paaiškejjo, oranžinè - mane tai nustebino ir t. t. Spalvų kieki galima modeliuoti pagal poreikį. Galima paprašyti nuolat tureti tokių kortelių. Mokytojui atkreipus dèmesi i mokinio darbą, jis gali pakelti atitinkamos spalvos kortelę ar skrituliuką, taip duodamas suprasti, kaip elgtis toliau.

- Telegrama - trumpas vieno sakinio apibendrinimas, skirtas tiksliai ir pagal galimybes greitai pasakyti ar parašyti savo nuomonę. Nežymiai sutrikusio intelekto mokiniai gali parašyti ir net labai trumpus sakinius, pavyzdžiui, man sekasi, viskas gerai, sunku suprasti, nerandu atsakymo, nematau miesto ir pan.

- Piešti pasiekimus atspindinčius oru prognozés ar kitus mokytojo ir mokinio sutartinius ženklus (pvz., besišypsantys ar liūdni veidukai). Kai patinka ir sekasi - mokiniai gali piešti gèles, saulę, gaubliukus, kai nesiseka - debesis, žvaigždes ir t. t. Šiuo atveju daug kas priklauso nuo mokinio asmeninių savybių, amžiaus, lyties ir geografijos mokytojo fantazijos.

- Spidometras - skirtas nustatyti tinkamą mokymosi tempą (1 pav.). Mokytojas gali greitai gauti informaciją apie pamokos spartumą ir tempo tinkamumą nežymiai sutrikusio intelekto mokiniams.

Mokiniai gali piešti pamokoje arba turèti jau paruoštą spidometrą. Svarbu, kad mokytojas matytų, ar mokiniams tinkamas pamokos tempas.

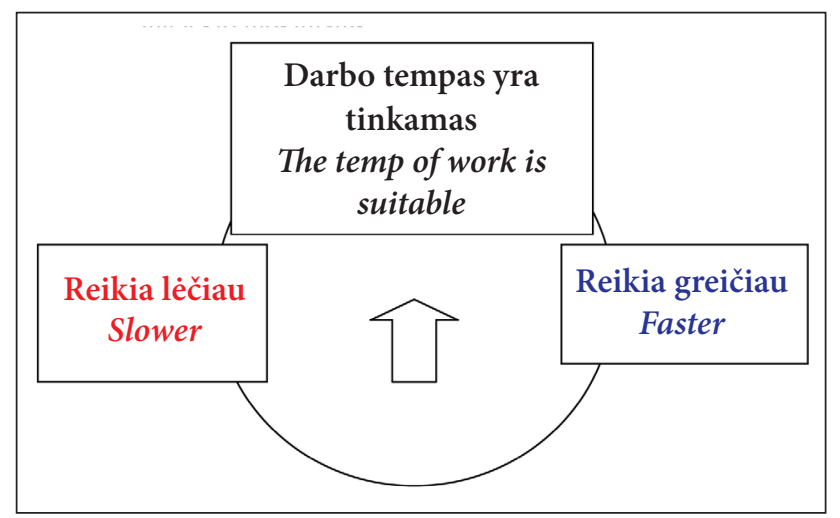

1 pav. Spidometras

Fig. 1. The speedometer 
- Nebaigtu sakiniu metodas - atlikus tam tikras užduotis ar jų dalį, geografijos mokytojas gali paduoti mokiniui popieriaus lape užbaigti vieną, du ar kelis sakinius. Metodas skirtas išsiaiškinti mokymosi privalumus arba sunkumus (2 pav.).

Apibendrinant šiuos pateiktus vertinimo ir įsivertinimo būdus ir metodus verta paminèti, kad šiame straipsnyje aptarti tik keli įmanomi variantai. Svarbu pabrèžti, kad lemiamą vaidmenị vaidina geografijos mokytojo kompetencija, jo kūrybiškumas, mokymo stilius, gebejjimas įvertinti mokiniu sutrikimus ir individualius poreikius, parinkti adekvačius mokymo(si) tikslui bei mokinio mokymosi stiliui tinkamus vertinimo metodus, igalinančius bet kokio lygio mokini patirti mokymosi sèkmę. Drąsiai galima teigti, kad geografijos pamoku, kuriose mokosi intelekto sutrikimų turintys mokiniai, organizavimas yra geografijos mokytojo meistriškumo išbadymas. Tik nuo mokytojo profesionalumo priklauso kokybiškos edukacinès aplinkos kūrimas, kur vienodai saugiai ir gerai jaučiasi ịvairių poreikių ir galimybių mokiniai.

\section{IŠVADOS}

1. Geografijos mokytojas, norèdamas sèkmingai mokyti ir ivvertinti nežymiai sutrikusio intelekto mokinị, pirmiausia turi būti labai gerai susipažinęs su jo vystymosi ypatumais ir dèl jų kylančiais mokymosi sunkumais. Šio intelekto sutrikimo mokiniai turi mokymosi sunkumų, kurie pasireiškia sutrikusiu suvokimu (lètesnis tempas; suvokimas menkai diferencijuotas ir apibendrintas, būdingas nepakankamas suvokimo aktyvumas), veiksminio ir loginio mąstymo stoka (nesugebejimas adekvačiai apibendrinti, abstrahuoti, lyginti, nustatyti loginius ryšius, santykius tarp daiktų ir reiškinių, daryti išvadas, spręsti uždavinius, planuoti ir numatyti rezultatus), dèmesio stoka, atminties specifiškumu (informacijos i̊siminimas, išlaikymas, atpažinimas ir atgaminimas), kalbos neišsivystymu bei emociniu nebrandumu (jausmų primityvumas, nepakankamas diferencijuotumas ar neadekvatumas konkrečiai situacijai, staigi nuotaikų kaita). Svarbu pabrèžti, kad kiekvienam mokiniui dalis ar net daugelis šiu ypatumų gali būti nebūdingi, nes mokinių specia-

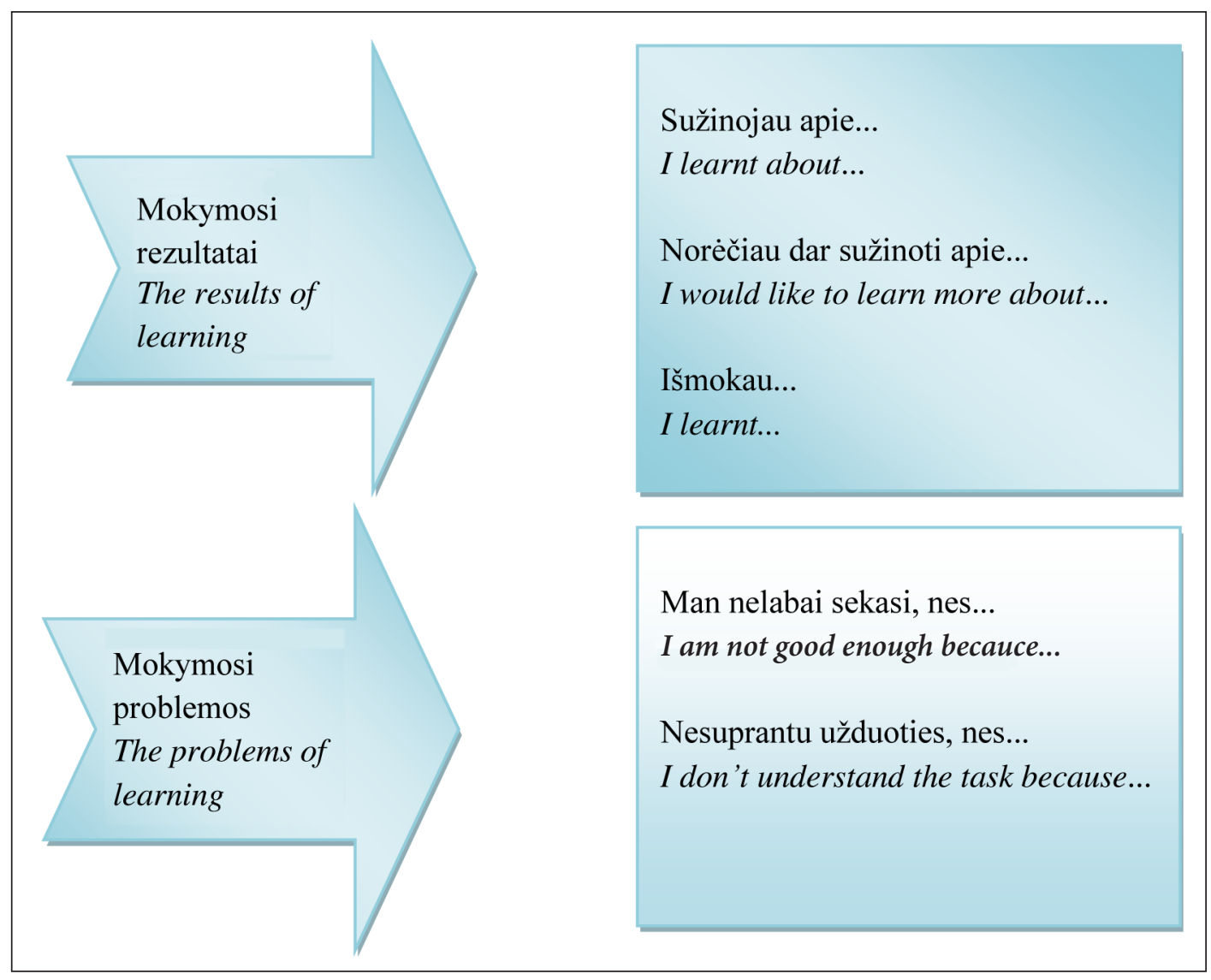

2 pav. Nebaigtų sakinių metodas

Fig. 2. The method of unfinished sentences 
lieji poreikiai ir sutrikimai būna labai ịvairūs. Todèl organizuojant geografinį ugdymą būtina atsižvelgti i kiekvieno konkretaus nežymiai sutrikusio intelekto vaiko unikalumą, pažinti jo asmenybę ir turèti žinių apie mokinio socialinę aplinką.

2. Šiuolaikinis vertinimas suprantamas ne tik kaip besimokančiojo žinių vertinimas, bet yra orientuotas $\mathfrak{i}$ besimokančiųjų asmenybinių galių plètojimą, adekvatų savo galimybių ir gebejimų vertinimą. Jis turi atspindèti ko mokomasi, kas išmokta, kokiais būdais ugdymo procesas vyksta, ar jis vyksta neignoruojant individualių besimokančiojo mokymosi tempu ir būdų atsižvelgiant ì besimokančiojo poreikius. Nežymiai sutrikusio intelekto mokinių vertinimas yra pritaikytas specifiniams poreikiams, kurie nulemia formuluojamus vertinimo tikslus, modelius, metodus, būdus ir tipus. Vertinant nežymiai sutrikusio intelekto mokinius geografijos pamokose taikomi formaliojo ir neformaliojo vertinimo büdai bei kaupiamasis vertinimas. Geografijos mokytojui svarbu vertinti šių mokinių žinias, igūdžius, bendrus ir dalykinius gebejjimus, nustatyti mokymo(si) pažangą, bet taip pat nuolat stebèti, kalbinti juos, diskutuoti, jausti grịžtamąji ryši. Remiantis mokslinès literatūros analize ir autorès patirtimi, labiausiai tinkantys geografijos pamokoms yra šie vertinimo ir isivertinimo metodai - individuali žodinė apklausa, apklausa raštu, testai, pristatymai, blyksnis, mozaika, nebaigtų sakinių metodas ir kt. Svarbu pabrèžti, kad lemiamą vaidmenį vertinant mokinius vaidina ir geografijos mokytojo kompetencija, jo gebejimas parinkti adekvačius mokymo(si) tikslui bei mokinio mokymosi stiliui vertinimo metodus, igalinančius bet kokio lygio mokini patirti mokymosi sèkmę.

Gauta 20150607 Priimta 20150728

\section{LITERATŪRA}

1. Ališauskas A. 2001. Specialiųjų ugdymosi poreikių tenkinimas bendrojo lavinimo mokyklose: pokyčių analizè. Specialiuju poreikiu vaiku pažinimas ir ugdymas: mokslinès konferencijos medžiaga. Šiauliai. 6-11.

2. Ališauskas A. 1996. Vaikǔ vystymosi ypatingumų pažinimas ir ịvertinimas. Šiauliai: ŠPI. 80 p.

3. Ališauskas A. 2002. Vaikų raidos ypatingumu ir specialiuju ugdymo(si) poreikiu juvertinimas. Šiauliai: ŠUL.
4. Ambrukaitis J., Ruškus J. 2002. Adaptuotos bei modifikuotos ugdymo programos: taikymo efektyvumo veiksniai. Specialusis ugdymas. 2(7): 6-23.

5. Ambrukaitis J. 1996. Specialiuju poreikiu vaikai. Šiauliai: ŠPI.

6. Ambrukaitis J. 2013. Žemu intelektiniu gebejjimu mokiniu ugdymas pagal adaptuota bendraja programą: tèvu ir mokytojų knyga. Šiauliai: Liucijus.

7. Bagdonas A. 1995. Sutrikimų klasifikacija. Vilnius: VUL.

8. Čiužas R. 2013. Mokytojo kompetencijos. Profesinio meistriškumo siekis. Vilnius: Edukologija.

9. Elijošienè I. 1998. Vaikai, turintys intelekto sutrikimų. Specialiujų poreikių vaikai. Šiauliai. P. 5-12.

10. Gage N. L., Berliner D. C. 1994. Pedagoginè psichologija. Vilnius: Alma litera.

11. Galkienè A. 2013. Specialiojo ugdymo kaita: nuo atskirties pripažinimo link. Vilius: Edukologija.

12. Garšvienė A., Ivoškuvienė R. 1993. Logopedija. Vadovèlis specialiosios pedagogikos studentams. Kaunas: Šviesa.

13. Giedrienė R. 2013. Specifiniai mokymosi sutrikimai ir vaiko socializacija. Vilnius: Edukologija.

14. Giedrienè R., Monkevičienè O. 1995. Kodèl nemiela mokykla? Vilnius: LRŠMM Leidybos centras. 90 p.

15. Indrašienė V., Žibènienė G. 2014. Pasiekimų vertinimas ir isivertinimas. Vilnius: MRU.

16. Kaffemanas R. 2005. Riboto ir nežymiai sutrikusio intelekto moksleivių kognityvinių gebejjimų ypatumai. Specialusis ugdymas. 1(12): 50-60.

17. Kraujutaitytè L. 2005. Vertinimas nuolatinio institucinio mokymo(-si) procese. Profesines studijos: teorija ir praktika. 1:29-34.

18. Kugelmass J., Ainscow M. 2004. Leadership for inclusion: a comparison of international practices. Journal of Research in Special Educational Needs. 4(3): 133-141.

19. Laužackas R. 2000. Mokymo turinio projektavimas. Kaunas. VDU leidykla. 143 p.

20. Mokiniu pažangos ir pasiekimu vertinimo samprata. Patvirtinta LR švietimo ir mokslo ministro $2004 \mathrm{~m}$. vasario 25 d. įsakymu Nr. ISAK-256. http://www.upc.smm.lt/ekspertavimas/biblioteka/ failai/samprata.pdf (žiūrèta 20150508 ).

21. Mokinių, turinčių specialiujų ugdymosi poreikių, ugdymo organizavimo tvarkos aprašas. Patvirtintas LR švietimo ir mokslo ministro $2011 \mathrm{~m}$. rugsèjo 30 d. ịsakymu Nr. V-1795. http://www.lsg.lt/failai/SPEC.TVARKOS\%20APRA\%C5\%A0AS.pdf (žiūrèta 20150408 ).

22. Pagrindinio ugdymo bendruju programu pritaikymo rekomendacijos. Specialiujų poreikių žemu ir labai žemų intelektinių gebejimų mokinių ugdymui. 2010. Vilnius: Švietimo aprūpinimo centras.

23. Pečiuliauskienė P., Barkauskaitė M. 2011. Pedagogines praktikos mokykloje vadovas. Vilnius: Edukologija. 
24. Petty G. 2008. Irodymais pagristas mokymas. Vilnius: Tyto Alba.

25. Pukinskaitè R. 1998. Riboto intelekto vaikai. Specialiujų poreikių vaikai. Šiauliai: Šiaulių universitetas. 134-141.

26. Specialiuju poreikiu mokiniu mokymosi pasiekimu vertinimo tyrimas (Šiaulių r. Kužių vidurinèje mokykloje). 2008. http://www.kuziai.siauliai.lm.lt/ index.php/veiklos-sritys/specialusis-ugdymas/64speciali-j-ugdymosi-poreiki-mokini-mokymosipasiekim-vertinimas (žiūrèta 20150423 ).

27. Stankutė A. 2011. Nežymiai sutrikusio intelekto vaiku ugdymosi ypatumai. http://kristianaweebly. weebly.com/uploads/1/8/5/2/18524958/nezymiai_sutrikusio_intelekto_mokiniai.pdf (žiūrèta 201312 20).

28. Subotkevičienè R. 2014. Nežymiai sutrikusio intelekto mokiniai geografijos pamokose: edukaciniai ypatumai. Tiltai. 67(2): 151-190.

29. Šiaučiukènienè L., Visockienè O., Talijūnienè P. 2006. Šiuolaikinès didaktikos pagrindai. Kaunas: Technologija.

30. The New Oxford Dictionary if English. 1998. Pearsall J. (red.). Oxford.

31. 2013-2014 ir 2014-2015 mokslo metu pagrindinio ir vidurinio ugdymo bendrieji ugdymo planai. Patvirtinta LR Švietimo ir mokslo ministro 2013 m. gegužès 27 d. İsakymu Nr. V-459. http:// www.smm.lt/uploads/documents/ugdymo-planai/BUP\%2020130519.pdf (žiūrèta 201505 04).

\section{Regina Subotkevičienè}

\section{SPECIFIC ASSESSMENT AND SELF-ASSESSMENT PRACTICES AND METHODS FOR STUDENTS WITH MILD INTELLECTUAL DISABILITIES AT GEOGRAPHY LESSONS}

\section{Sum mary}

One of the major features of modern education systems is to create conditions for students with mild intellectual disabilities to learn according to programs adjusted to their individual skills and abilities and to apply special training practices and methods for achievement of optimal learning achievements. In order to ensure high quality of education for students with special needs teachers are supposed to plan thoroughly their teaching activity, i. e. to select relevant teaching aids and forms and to create adequate learning atmosphere. Yet involvement of students in each other's assessment and self-assessment activities is another important prerogative of teacher's effective work. The present article is devoted to specific assessment and self-assessment practices and methods for students with mild intellectual disabilities at geography lessons. It is based on analysis of literary sources, re- sults of empirical investigations and author's individual practical experience.

The aim of the article is to survey the specific features of methods and practices applied during geography lessons for training students with mild intellectual disabilities to assess each other and themselves.

The main tasks are the following:

1. To discuss the specific abilities of students with mild intellectual disabilities and difficulties affecting their learning achievements and self-assessment;

2. To present some assessment and self-assessment methods helping to organise the teaching/learning process during geography lessons for students with mild intellectual disabilities.

Research methods are analysis of scientific literary sources and results of empirical investigations.

For successful training and evaluation of students with mild intellectual disabilities, teachers of geography must be well aware of the specific character of their intellectual development and the related learning difficulties. The students with mild intellectual disabilities have perception disorders, they lack logical thinking and concentration, their memory is specific, their language is poor and they are emotionally immature. Yet it should be born in mind that some or even the majority of these features may be absent as the special needs and impairments of students with intellectual disabilities are rather variable. Therefore, the organisation of the process of teaching/learning geography must be based on the understanding of the uniqueness of every student with mild intellectual disabilities and knowledge of his personality and social environment.

For evaluation of students with mild intellectual disabilities during geography lessons formal and informal evaluation techniques are applied. It is very important for the teacher of geography to appreciate the knowledge and skills of students, their general and subject abilities and the progress made. The informal accumulative evaluation (individual interviews, discussion and reciprocal understanding) is also very important. Based on the author's individual experience, the most relevant methods of assessment and self-assessment during geography lessons are the following: individual verbal inquiry, inquiry in the written form, tests, presentations, flash, mosaic, method of incomplete sentences, etc. Yet it is of primary importance to bear in mind that teacher's ability to select adequate teaching aims and the assessment methods that ensure the best learning achievements for students of whatever intellectual level plays a decisive role in the teaching process.

Key words: mild intellectual disabilities, learning difficulties, assessment and self-assessment, geography lessons 